\title{
The historical development and challenges of Islam in Ila-Orangun, Nigeria
}

\author{
R. Ibrahim Adebayo \\ Department of Religions, University of Ilorin, Ilorin, Nigeria \\ E-mail:adrafhope@yahoo.com; rafiu@unilorin.edu.ng
}

\begin{abstract}
Like many other Yoruba towns in the south-western Nigeria, Ila-Orangun which is popularly referred to as the principal town of Igbominaland witnessed the coming of Islam during a period when paganism had eaten deep into the fabric of every sphere of life of the people. The uniqueness of Islam in the town is that it has not been able to bring to an end the traditional belief system of the people ever since its inception. This is probably because of the status of the town as one of the towns founded by one of the sons of Oduduwa from the great ancestral land, Ile-Ife. This paper therefore takes a look at the inception of Islam in this ancient town to determine the extent of influence of traditional belief system on the practice of Islam in it and the methods adopted by the early Muslim clerics to penetrate the town with a view to breaking the genes of darkness in the town. Attempts are also made to discuss some latest developments on Islam in town, namely Imamship tussle and other challenges facing the Muslim community there. The paper concludes by identifying some steps necessary to be taken by the Muslim community in the town for them to be able to place the religion on a better pedestal.
\end{abstract}


Seperti banyak kota-kota Yoruba lainnya di selatan-barat Nigeria, Ila-Orangun yang populer disebut sebagai kota utama Igbominaland, menyaksikan kedatangan Islam selama periode ketika paganisme telah mengakar jauh ke dalam setiap bidang kehidupan masyarakat. Keunikan Islam di kota ini adalah bahwa Islam belum mampu membawa pada berakhirnya sistem kepercayaan tradisional masyarakat sejak awal. Ini mungkin karena status kota sebagai salah satu kota yang didirikan oleh salah satu putra dari Oduduwa dari tanah leluhur besar, Ile-Ife. Oleh karena itu tulisan ini berupaya melihat perkembangan awal Islam di kota kuno ini untuk mengetahui sejauh mana pengaruh sistem kepercayaan tradisional pada praktek Islam di dalamnya dan metode yang diadopsi oleh para ulama Muslim awal untuk menembus kota dengan maksud untuk menerobos kegelapan di kota ini. Paper juga berupaya untuk membahas beberapa perkembangan terbaru tentang Islam di kota ini, yaitu soal ke-imaman dan tantangan lain yang dihadapi masyarakat Muslim di sana. Makalah ini menyimpulkan perlunya mengidentifikasi beberapa langkah yang diambil oleh komunitas Muslim di kota ini agar mereka dapat menegakkan agama Islam pada alas yang lebih baik.

Keywords: Islam; Ila-Orangun; Oba; Development; Challenges

\section{Introduction}

Ila-Orangun is a faction of the Igbomina, a heterogeneous sub-group of the Yoruba ${ }^{1}$ which had a vast territory extended to the south-eastern banks of River Niger up to Jebba. ${ }^{2}$ Historically, the entire Igbominaland was a territory of Orangun of Ila, the head of all Igbomina race in Yorubaland. However, the Orangun lost substantial part of his land consequent upon the intrusion of the Nupe and that of jihadists from the north. ${ }^{3}$

\footnotetext{
${ }^{1}$ The Yoruba are found in the south-western part of Nigeria. Predominantly, they are found in the Ogun, Oyo, Ondo, Lagos, Ekiti, Osun and part of Kwara and Kogi states of Nigeria.

${ }^{2}$ B.A. Salam, Ajase-Ipo (A Foremost 'Ogbo' Bearer) in Focus. A publication of Directorate of Information \& Protocol, Palace of Olupo of Ajase-Ipo, 2010, 12.

${ }^{3}$ E.O. Ibiloye, "Diplomacy and Emirate Formation: The Integration of the Igbomina into the Ilorin Emirate in the $19^{\text {th }}$ Century", African Nebula, volume 1, no 1 (2010), 76.
} 
Tradition of origin of Ila-Orangun suggests that the town was founded by one of the seven children of Oduduwa, the progenitor of the Yoruba, who incidentally departed from Ile-Ife, the cradle of the Yoruba. Historians are however not unanimous on which of the children who actually led the people of Ila out of Ile-Ife. Names like Fagbamila Oran mi gun Ajagun-nla, Anasin Adetinrin and Iwa were mentioned. ${ }^{4}$ The people of Ila believed in the existence of a Supreme Being known as Eledunmare who was so mighty that He could not have direct dealings with His creatures except through demi-gods and divinities like Sango, ${ }^{5}$ Oya, ${ }^{6}$ Osun, ${ }^{7}$ and Obatala. ${ }^{8}$ As a result, these divinities were worshipped through physical phenomena like rocks, hills, trees, rivers and stones.

By virtue of antiquity and ancestry, Ila-Orangun was predominantly a traditional society. They were so engrossed in traditional worships that hardly could a month pass without the celebration of one traditional festival or the other. In the same vein, virtually all the main houses had one deity or the other to which homage was paid. The predominant worship divinity was Ifa which was consulted usually from time to time, especially before embarking on missions and to project into the future. ${ }^{9}$ Ifa divinity was usually consulted before embarking on journeys, marriage, business adventures and when a child is born in a family. Most importantly, it is mandatory for Ifa oracle to be consulted before a new

\footnotetext{
${ }^{4}$ Segun Ajiboye, A History of Ila-Orangun, Ife-Ijebu, Adeyemi Press Limited, 1993, 4.

${ }^{5}$ Sango is the traditional Yoruba god of thunder and lightning.

${ }^{6}$ Oya is the goddess of the River Niger. She was the first wife of Sango the god of thunder.

${ }^{7}$ Osun is the goddess of river Osun which flows through some towns in Yorubaland particularly Osogbo, the capital city of Osun State. She was believed to be one of the wives of Sango.

${ }^{8}$ Obatala is the Yoruba arch-divinity. He is believed to have been delegated by God to create the solid earth; he is also regarded as the creator divinity commissioned by the Supreme Being to mould the physical form of man. He is otherwise called Orisa-nla.

${ }^{9}$ Segun Ajiboye, A History of Ila-Orangun..., 52.
} 
king was appointed and installed; this was to determine the prosperity or adversity, peace or upheaval that the reign of such king would bring to the community. The Ifa priest to avert evil consequences or to ensure sustainability of positive things usually prescribed appropriate sacrifices. ${ }^{10}$ Of importance was also the Ogun worship, which festival which was always celebrated in the month of June or July each year. The period featured Ewe a female youth organisation members who were drawn from the ruling houses of Arutu, Igbonnibi and Okomo of Ila-Orangun. The object of the sacrifice to Ogun varied from dog, sheep or pig as prescribed by Ifa Adagba who used to unfold all the requirements needed for the festival. ${ }^{11}$

Another popular festival was Oke festival which was commonly celebrated annually by the Arutu ruling house for the commemoration of the demise of Oba Arutu Oluokun who was said to have 'sank' at Para Oke as a result of old age. In addition, like other Yoruba towns, Egungun festival was also prominent among the people of Ila-Orangun. The celebration of the festival was usually based on the imagination that the spirit of the ancestors came on visitation. ${ }^{12}$ Notable Egungun from IlaOrangun were Egungun Oja, Egungun Oloponda and Egungun Ila. While Egungun Ila is celebrated once in every two years in the month of March/ April, Oja is held annually for seven days in the month of August. ${ }^{13}$ There was also Oro festival, which attracted crowd in the town as everyone was expected to be in attendance during the celebration. Aworo Ose festival was celebrated once a year to commemorate a powerful hunter who was

${ }^{10}$ J.A. Awolalu \& P. A. Dopamu, West African Traditional Religion, Ibadan: Onibonoje Press \& Book Industries, 1979, 80.

${ }^{11}$ A. Olaniyan, "Deities in Ila-Orangun" in Ila-Orangun (the Principal City of Igbomina People), Osogbo: Swift Prints Nig. Ltd, 2000, 53-55.

${ }^{12}$ O. Abimbola, "Oke Festival" in Ila-Orangun (the Principal City of Igbomina People), Osogbo: Swift Prints Nig. Ltd, 2000, 56-59.

${ }^{13}$ Segun Ajiboye, A History of Ila-Orangun..., 54. 
said to have come to rescue the people of Ila from a frightful and dangerous bird, which terrorised the people. The traditional religious beliefs of the people of Ila-Orangun were however interrupted by the introduction of Islam and Christianity. This is not to suggest that the advent of Islam totally eradicated the traditional practices because in recent times, these traditional festivals and practices are still observed though with a drastic reduction in patronage and participation.

\section{The coming of Islam to Ila-Orangun}

Like many other Yoruba towns, the date of introduction of Islam to IlaOrangun could not be precisely mentioned. However, two main oral sources of information are relied upon while writing on the history of Islam in the town. The first version of it attaches the introduction of Islam to the town to the arrival of an itinerant preacher from Borno to the town in the $18^{\text {th }}$ century. He was Muhammad Mustafa ibn Ibrahim who was said to have been accommodated at Olori Awo's compound. ${ }^{14}$ His preaching activity in the town was a little bit fruitful as he was able to get few people converted to Islam. The preacher also received royal patronage possibly because of the general hospitality of the traditional ruler to accommodate any stranger that came to his town, or rather by virtue of the normal practice of any stranger with a mission to first pay homage to the traditional ruler of the town for accommodation or for acceptance. ${ }^{15}$ However, the mode of worship of the Mallam was strange to the people that they used to flock his residence to watch him while praying, and through this, some were fascinated to the religion and so accepted it.

The second version of the information traces the history of Islam in Ila to a woman called Nana Awawu Aanike, the daughter of one Aafa

14 Segun Ajiboye, A History of Ila-Orangun..., 59.

15 R.I. Adebayo, "The Role of Traditional Rulers in the Islamization of Osun State (Nigeria),” Journal for Islamic Studies, 30 (2010), 66-68. 
Aaliki from the Northern part of Nigeria. It was said that the woman came to reside in Ila-Orangun based on the instruction that her barrenness could only become a thing of the past only if she could come down to any forest region. On getting to Ila-Orangun, she met a prince who was the first son of Orangun Okomokasa by name Chief Akingboye Obasolo Tako who finally led her to the altar. The spirit of religious tolerance made the prince to allow his wife to perform her religion freely. ${ }^{16}$ The marriage was blessed with a boy named Olajojobi Agboluaje who eventually became a king between 1745-1820CE. The family of Agboluaje therefore added to its cognomen the following: "Agboluaje omo aafa Aaliki to komole wola, boo ba kewu tan ko sadura fun mi;" meaning: "Agboluaje, the child of Aafa Aaliki who brought Islam to Ila-Orangun. If you finish your Arabic recitation, pray for me." ${ }^{17}$

The above not-withstanding, the $19^{\text {th }}$ century Jalumi war came as a cog in the wheel of development of Islam in the town. Following a hint that the Ibadan people were coming to invade Ila during the hegemony of Oba Bamgboye Ariyowonye (1820-1876CE), the king who believed he could not withstand the Ibadan army thought it wise to seek refuge in Omu-Aran, an Igbomina town in the Ilorin Emirate. The people of Ila therefore dispersed to various places including the then Imam of the town, Imam Muhammad Badiru who fled to Ilorin with his people. This incidence constituted a serious setback to the development of Islam in the town.

Oba Adeyemi Amesomoye (1876-1908 CE) who ruled after Oba Bamgboye brought his people from exile and resettled them at the present Ila. In his attempt to consolidate the town, he appealed to those who had fled to come back home. His appeal was responded to positively by people.

${ }^{16}$ R.I. Adebayo, "The Role of Traditional Rulers"..., 70-71.

${ }^{17}$ Oral interview conducted with Alhaji Adeniran, the eldest Muslim cleric in Ila-Orangun and the leader of the League of Alfas in Ila Local Government Area. Interview held at his house in Isedo on $23^{\text {rd }}$ June 2012. 
He however noticed a vacuum in the absence of the Imam of the town who refused to come back to the town. He therefore sent an emissary to the then Emir of Ilorin, Sulayman Momoloso to persuade Alfa Badiru to return to Ila. Alfa Badiru was invited by the Emir and there, he expressed his unwillingness to go back to Ila because of old age, but persuaded the Emir to allow one of his sons to go and replace him. Thereafter, his son Alfa Ibrahim who was sojourning in Iwo was sent for and was turbaned as the Imam at the Emir's palace before being sent to Ila-Orangun. ${ }^{18}$

In 1892, the mosque at Olori-Awo compound which was the first mosque was constructed. Later another ratibi mosque was established at Isale-Imole area of Eyindi now called Isale Aafa mosque with Alfa Ahmed as its first Imam. However, when the Olori-Awo mosque could no longer accommodate the Muslim congregation, and it was difficult to expand the mosque further, an appeal was made to the King for allocation of more spacious land, and this was granted by allocating a new land between Obajoko and Oja oba markets to the Muslims. ${ }^{19}$ The foundation stone of the present central mosque was laid during the reign of Orangun Gbadamosi Adedapo Agboluaje II (1947-1960) on 15th July 1948. Meanwhile, the frontage of the mosque which was used as Motor Park was allocated to the Muslim community by the immediate past Orangun, Oba Williams Ayeni Adetona.

\section{Some factors responsible for the spread of Islam in Ila-Orangun}

Some factors that were responsible for the spread of Islam in Ila-Orangun have been identified by us in our previous work. ${ }^{20}$ For the purpose of

\footnotetext{
${ }^{18}$ Oral interview conducted with the immediate past Chief Imam of Ila-Orangun, Alhaji Usman Ayinla Kolawole on $12^{\text {th }}$ June 1995.

${ }^{19}$ R.I. Adebayo, "The Role of Traditional Rulers"..., 72.

${ }^{20}$ See, R.I. Adebayo, "The Introduction, Spread and Impact of Islam in Ila-Orangun" in Ila-Orangun, the Principal City of Igbomina People, Osogbo: Swift Prints Nig. Ltd, 2000, 84110.
} 
brevity, some of these factors are recapitulated here. In the first instance, the early Muslim mallams in the town were friendly with their hosts, drinking and dinning with them without discrimination. The spirit of liberalism and soft-mindedness of the early Muslim leaders in the town was so demonstrated to the extent that Imam Muhammad Ibrahim was said to have followed Orangun Adeyemi Amesomoye to the occasion of Isinro, a traditional programme in the town, and that Imam Rufai Ahmadu was said to have gone to meet the leaders of traditional faith at Kaa Etu'fe.

In addition to the above was the humanitarian duty of the early Muslim leaders in attending to their hosts' spiritual needs. In most cases, the Mallams combined healing with their religious duties by prescribing concoction for their patients in form of tira usually wrapped in animal leather for healing and protection. The efficacy of such prescription convinced many and so they developed interest in the religion. ${ }^{21}$

Moreover, the religion of Islam seemed to have similarity with the traditional religion professed by the Ila people. For instance, the religion did not go against living polygamous life as long one had not gone beyond the stipulated maximum number of four wives and provided one could maintain justice and fair-play among them. Also, the early Muslims practised their Islam with syncretism; tapping wine, taking wine and selling wine. Adebayo observed that the Muslim Mallams were aware of these unwholesome practices, but only adopted the Islamic principle of gradualism to encourage and allow the converts to be convinced of the evils of those practices themselves without being coerced..$^{22}$

${ }^{21}$ Traditionally, Muslim clerics in Africa are believed to be custodians of powerful and effective charms and amulets, hence people used to rush to them for spiritual remedy to their problems. The engagement of the occult experts by traditional rulers in Yorubaland served as great momentum for the spread of Islam in the domain. 89.

${ }^{22}$ R.I. Adebayo, "The Introduction, Spread and Impact of Islam in Ila-Orangun”..., 88- 
The religion of Islam seemed to have attracted the people through its annual festivals of Ileya ('Idul ad-ha) and itunnu awe ("idul-fitr). During the period, drummers went from house to house making merriment while ram meat was distributed freely without discrimination.

Finally, the early Muslim mallams were not tired of organising public sermon to educate the masses of the beauty of Islam and to kick against traditional worshippers who were at logger head with them severally. Some spiritual steps were also taken to attract people to the religion. In an interview with the immediate past Chief Imam of Ila-Orangun, Shaykh Uthman Kolawole admitted the use of charm to invite people to Islam in its early days in Ila-Orangun. He confessed that drum was used to convert many people into Islam by employing special charm to the drums, so that anybody who heard the sound of such drums would start dancing and consequently joined the fold of Islam. ${ }^{23}$

\section{Trend of development}

Islam became a popular religion in Ila-Orangun with the untiring efforts of the early Muslim scholars in the town. The emergence of different Islamic brotherhood and organizations assisted a lot in the rapid spread of Islam in the town. These shall be discussed under the following headings: Adoption of Muslim Brotherhood (Sufism), establishment of Qur'anic schools and other educational institutions, proliferation of Muslim youth organizations, Islamic chieftaincy titles, visitation of important dignitaries to the town, and Imamship issue.

\section{Adoption of Muslim brotherhood (Sufism)}

The move for spiritual development made some Muslim individuals to embrace the Tariqahs. According to oral information, the Tijaniyyah

\footnotetext{
${ }^{23}$ R.I. Adebayo, “The Introduction, Spread and Impact of Islam in Ila-Orangun”..., 89.
} 
Brotherhood was said to have been introduced to Ila in 1944 when Alhaji Muhammad Raji Obaloja popularly called Alhaji Agba was initiated into the order in 1939 by Muqaddam Muhammad Lawal from Erin-Osun. ${ }^{24}$ Initially, Alhaji Agba used to perform the tariqah's rituals privately in his house. It however became a public consumption in the town in 1964 when Alhaji Sheikh Salahudeen (a.k.a. E ma kirun) who visited Ila for public preaching from Oyo in Oyo State, formerly launched the Tijaniyyah Sufi Order. Through his efforts many prominent Ila Muslim personalities like Alhaji Ibrahim of Aworo's compound, Alhaji Alimi Adeniran, Alhaji Abdul-Ganiyy from Iwo, Alhaji Asiyanbi Komolafe and Alhaji Akinsola were initiated into the tariqah. In 1961, Alhaji Shaykh Ibrahim Idowu Alakoniyi, the current Khalifatul-Khulafa' of Osun State was initiated into the Tijaniyyah Tariqah by Late Muqaddim Abdur-Rahman Ghata from Ilorin. ${ }^{25}$

In addition to the above, the Qadriyyah Order was introduced into the town by a prominent preacher, late Shaykh Najimud-Deen a native of Ibadan. The Shaykh actually assisted the Ila Muslim community in the renovation of the Central mosque by raising funds at every public lecture he organised in the town, and as well, championed the felling of some age-long 'mysterious' trees in some areas of the town. Some of the Qadriyyah members in the town were the immediate past Imam of Taosiri mosque, Alhaji Ajao; the Ajanasi of Ila, Alhaji Muhammad Bello, and Alhaji Jamiu Jibril (a.k.a. Malaika).

It is of note that these Sufi Orders are contributing positively to the development of Islam in the town. Apart from the annual Maulud Nabiyy

\footnotetext{
${ }^{24}$ Oral interview conducted with the Khalifatul-Khulafa of Tijaniyyah Brotherhood in Osun State, Alhaji Shaykh Ibrahim Idowu on $10^{\text {th }}$ March 2010.

${ }^{25}$ Oral interview conducted with Alhaji Shaykh Ibrahim Idowu Alakoniyi, the KhalifatulKhulafa' of Tijaniyyah Brotherhood, Osun State on 10 ${ }^{\text {th }}$ March 2010.
} 
celebrations by these Orders, some of them have Arabic and Islamic schools as well as nursery and primary schools.

\section{Establishment of Qur'anic schools and other educational institutions}

Like other towns Islam spread to, the establishment of Qur'anic schools quickly followed the introduction of Islam to Ila-Orangun. Most of the schools initially took place in the front of the house of the mallams or in some mosques' verandas. It should be noted that those who were devoted to the religion did not hesitate to pursue Qur'anic education. Alhaji Muhammad Raji (Alhaji Agba) was said to have left Ila for Ibadan to receive Qur'anic education. On his arrival, he established his own Qur'anic schools where Muslims were taught Arabic language and Islamic tenets. ${ }^{26}$ Alhaji Muhammad Raji of Agbarajamo's compound, the current Mufassir of Ila has tried a lot in training many Ila sons and daughters in his school which had taken place in different streets of the town, namely Ita-Sapon's mosque, Oke-Ede area, Ila central mosque and currently in Agbarajamo's compound. The products of the schools have been firmly established at different capacities after graduating from the school. They include Shaykh Zakariyyah Badamosi Adekilekun, a proprietor of an Islamic nursery and primary school in Osogbo; Alhaji Abdul-Yekeen Badamosi, a prominent preacher in Lagos; the current writer, and Dr Adebayo Tajudeen a Senior Broadcaster at the Voice of Nigeria (VON), Lagos, to mention but a few.

It also needs to be mentioned that some Qur'anic schools which started in front of mosques had and are still producing students who are well versed in Islamic education. Products of these schools go to other towns like Ilorin, Ibadan and Iwo to further their studies. Some of them have

\footnotetext{
${ }^{26}$ Oral interview conducted with Alhaji Abdur-Razaq Raji, the proprietor of Al-Hikmah Group of Schools, Ila Orangun on 10 th $^{\text {th }}$ March 2014.
} 
gone to as far as Cairo, Malaysia, Jeddah, Makkah and Madinah and have graduated from there. Alhaji Abdul-Azeez Balogun and Alhaji Shuaib Balogun of blessed memory were products of Al-Azhar University, Cairo. Others who had graduated from Cairo are Alhaji Ibrahim Imam Kolawole and Alhaji Is-haq Imam Kolawole. Among the products of Islamic University, Madinah are Alhaji Abdur-Razaq Muhammad Raji, Alhaji AbdulHamid Salahudeen, the current Chief Imam of Ila-Orangun, Alhaji Muhammad Raji, the current Naibul-Imam of Ila and Alhaji Abdullah Komolafe. Alhaji Abdul-Yekeen Badamosi is a product of a university in Riyadh. In pursuance of spiritual education, Khalifah Ibrahim Idowu of Alakoniyi's compound also went to Kaolaq in Senegal in 1972 where he visited Sheikh al-Islam, Ibrahim Niyas. ${ }^{27}$

As a result of the Arabic knowledge acquired by some Muslims in the town, some of them had embarked on writing and publishing Arabic and Islamic texts. Alhaji Akewukowo is popular among those who produce Hijrah calendar every year. Alhaji Abdul-Azeez Balogun of blessed memory has promoted and publicised the name of Ila through the publication of the popular prayer book titled Ghayat al-Maqsudah. The book is highly recognised among Imams and alfas and it is being used throughout the federation and even beyond by the Muslims. Other books published by him in both Arabic and Yoruba languages are Iwe Aniyan; Imo la ladinni, A koni lesin and Kitab Tuhfatul Imam Ratibi among others. Alhaji Yahya Ekundayo Imam of blessed memory equally wrote a lot in English and Yoruba. He was prominent in writing on comparative analysis of Christianity and Islam as well as story of prophets. The Mufassir of the town, Shaykh Muhammad Raji Balogun has equally published a prayer book titled Majmu'at An-Nafi'at.

${ }^{27}$ Oral interview conducted with Alhaji Shaykh Ibrahim Idowu Alakoniyi. 
It needs to be mentioned that the Ila Muslims were not active in the sphere of the Western education as they were in the Arabic education. For fear of losing their wards' religious identity, many Muslim parents did not sponsor their children to the existing primary schools then. It should be mentioned that Christianity was introduced to Ila in about 1906 by Pa Jonathan Opadina of Anglican Denomination. The Roman Catholic Mission was introduced to the town in 1909 by Pa Agbolade Atobatele. With the introduction of Christianity to the town, the Western system of education was introduced. The Christian Mission schools had started operation in the town as far back as 1912 when the Saint Mathew's Anglican Primary School was established. The Native Authority School was established in 1931 following the visit of the colonial Resident Officer to the town that year. ${ }^{28}$ In the same vein, the Saint Julius Catholic School and the Baptist Day School were established in 1945. It was later in 1946 that the Muslims stood up to establish their own school named Ansar-Ud-Deen School at Oke Ola. The population of the school rose astronomically that it became necessary for the school to be divided into two schools namely A.U.D. School I and A.U.D School II. Later in 1964, the Local Authority School, Ora Road which was established in 1955 was renamed Ansar-Ud-Deen School, to attract Muslim population residing in the area to send in their children. ${ }^{29}$

In addition to the above, in line with the National Policy on Education which encourages private individuals, organizations and communities to establish private schools and which exclusively leaves the provision of pre-school education to private and voluntary enterprises on the basis

\footnotetext{
${ }^{28}$ F. Adeniji, "The Introduction, Spread and Impact of Christianity in Ila-Orangun, in Ila-Orangun, the Principal City of Igbomina People, Osogbo: Swift Prints Nig. Ltd, 2000, 111130.

29 R.I. Adebayo, "The Introduction, Spread and Impact of Islam in Ila-Orangun..., 101.
} 
that every society has the right to determine what it hopes and wishes its young and innocent citizens to learn, Muslim individuals and organizations in the town have risen to the task of establishing nursery, primary and secondary schools. The first Islamic nursery and primary school in Ila is Nurudeen International Nursery and Primary School. This was quickly followed by Al-HudaModel School which was established in 1992. Others that followed include Al-Hikmah Nursery and Primary School and Tijaniyyah Nursery and Primary School to mention but a few. The existing private Islamic secondary schools in the town are Nurudeen Grammar School and Al-Huda College among few others.

\section{Proliferation of Muslim groups, societies and youth organizations}

The proliferation of Islamic societies in Ila-Orangun is a clear evidence of the development of Islam in the town. One of the early societies to be established in the town is the Ansar-Ud-Deen society. The Nurudeen Islamic Mission was founded in 1979 by late Alfa Isa Ariyo with Ila being the headquarters and branches in towns like Iresi, Eripa, Ibadan, Shagamu, Lagos and Offa, to mention but a few. ${ }^{30}$ On April 27, 1984, the Ahmadiyyah Movement was formally launched in Ila-Orangun with Brother Tajudeen Abdul-Azeez, a native of Ibadan as the first Chief Imam of the Movement. The personalities of Professor Abdul-Hamid Fakeye, Alhaji Ibrahim Akin Fakeye, Brother Abdul-Azeez Adeniran and Late Yusuf Jimoh were the brain behind the introduction of the Movement to the town. ${ }^{31}$

The first Muslim youth organization in Ila-Orangun was the Young Islamic Missionary Association of Nigeria (YIMAN) which was established

\footnotetext{
${ }^{30}$ Oral interview conducted with Alhaji Imam Alatise, the Chief Imam of Nurudeen Islamic Mission, Ila-Orangun, on $9^{\text {th }}$ March, 2012.

${ }^{31}$ Oral interview conducted with Bro. Tajudeen Abdul-Azeez, the first Chief Imam of the Ahmadiyyah Movement in Ila-Orangun on $5^{\text {th }}$ March 1989.
} 
in the '70s with Shaykh Muhammad Raji Balogun and Late Alhaji Yahya Ekundayo playing significant roles in its establishment. The Ila Local Government Branch of the National Council of Muslim Youth Organizations (NACOMYO) has its headquarters at Ila with about fourteen different Islamic youth organizations under its umbrella. Although, NACOMYO is still functioning, most of its member organizations have gone into a state of oblivion. The Branch was noted for organising annual Hijrah celebration in the town. The programme used to feature among other events visitation to the General Hospital to pray and offer gifts to the sick ones, friendly football match, symposium, lecture, Qur'anic competition, quiz competition, and procession round the town on the eve of the grand finale of the celebration. The grand-finale of the programme used to come up at the 'Id praying ground and it used to feature lecture and match-past among Arabic school student, private schools and secondary school students. ${ }^{32}$ Of recent, NACOMYO has being championing the annual Oba Abdul-Wahab Oyedotun Ramadan Lecture which had featured important international Muslim preachers like Dr. Imam Ya'qub Aliagan from the University of Ilorin, Shaykh Muhyideen Salman Husain, the Chief Imam of Offa and Engineer Taofiq Abdul-Hamid, the Chief Imam of the Federal Polytechnic, Ede.

Apart from NACOMYO, Ila-Orangun could also boast of other prominent organizations like the Federation of Muslim Women Associations (FOMWAN) and other Asalatu Groups like NASFAT and Quareeb.

\section{Islamic chieftaincy title holders}

In order to integrate the well-to-do people into the affairs of Islam in the town, some important personalities have been turbaned with some Is-

${ }^{32}$ This author has been the coordinator of the Ila chapter of NACOMYO and under him these programmes had been executed. 
lamic chieftaincy titles. The immediate past Chief Imam of Ila had carried out this responsibility of turbaning such personalities as late Alhaji Amusat Adebisi Folorunsho as Aare Muslumi of Ila Local Government; Alhaji Olayiwola Ibitoye (Mosalasi E) as Seriki Adinni; late Alhaji Tiamiyu Oladipo as Balogun Adinni, and Alhaja Raliat Onafuwa Opeloye as Iya Adinni of Ila Local Government. These title holders have been performing well in their offices. For instance, most of them used to donate heavily towards some religious programmes, while their presence at religious programmes has been adding flavour to Muslim programmes in the town. Alhaji Amusat Folorunsho initiated the Muslims' acquisition of a vast land along Ila-Agbamu Road for projects that are Islam-inclined in future. Alhaja Onafuwa equally constructed a modern Jum'at mosque along Ila-Osogbo Road where students of Ila Gammar School observe their daily and Jum'at prayers. The current Chief Imam of the town has also turbaned Dr. Bashir Gbadamosi, the Acting Provost of the Osun State College of Education, Ila Orangun, the Aare Muslumi of Ila Local Government and Alhaja Sikirat Adebayo the Iya Sunna of the local government.

\section{Visitation of important dignitaries to the town}

Islam has served as a vehicle that brought many important Muslim personalities to Ila-Orangun. These august visitors have come to witness and participate in one Islamic programme or the other, while some came to preach Islam to the people. The coming of Alhaji Shaykh Salahu-deen to Ila in 1964 was instrumental to initiation of many people in Ila into the Tijaniyyah Order. In 1971, Shaykh Sherifdeen Abdul Majid visited Ila from Sudan. The efficacy of his prayer made many people to join the Tijaniyyah as well. ${ }^{33}$ Alhaji Shaykh Najimu-Deen from Ibadan also vis-

\footnotetext{
${ }^{33}$ Oral interview with Shaykh Ibrahim Idowu, the Khalifatul-Khulafa' of Tijaniyyah in Osun State.
} 
ited Ila and got some people initiated into Qadiriyyah Order. In the same vein, the visit of Alhaji Alade Adura to Ila marked the establishment of the Nasirudeen Islamic Society in the town. Other important Muslim preachers who had come to Ila and had made remarkable impact on the Muslims of the town were Alhaji Omisore of blessed memory from IleIfe; Alhaji Muhyideen Bello, an international preacher from Kano; Akewu-gba-Jesu, Alhaji Lanrewaju Adepoju, Shaykh Muhyideen, the Chief Imam of Offa; Engineer Abdul-Hamid Taofiq, the Chief Imam of the Federal Polytechnic Ede; Dr. Abubakr Ya'qub Aliagan of the University of Ilorin, and Late Alhaji Abdul-Azeez Ajagbe-mo-keferi, to mention but a few.

It is important to mention that the visit of these personalities had influenced the way of life of the people of the town. Many of these visitors were endowed with supernatural powers with which they solved the problems of those who came to them for spiritual assistance. For instance, Shaykh Sherif-Deen from Sudan was said to have cured two people who were suffering from schizophrenia. Also, both Muslims and non-Muslims flocked the house of Alhaji Alade Adura to seek spiritual solution to their problems, while some who possessed witchcraft were said to have confessed and were treated accordingly by the Shaykh. In addition to this, he organised special prayers for the town where both Muslims and non-Muslims participated in trekking to all the four entrances to the town where prayers were offered for the peace and progress of the town.

\section{Imamship issue}

Right from the inception of Islam in Ila-Orangun, the Muslim community had no problem in the appointment of the Chief Imam of the town. The town adopted hereditary system of succession, as the office of the Imam had been occupied exclusively by a family possibly because the fam- 
ily had been the most knowledgeable in Islam and so was allowed to present the Imam. With the development of Islam as well as the extension of Islamic knowledge beyond a particular family, an attempt to change the status quo was made soon after the death of Shaykh Imam Busari Kolawole in 1975. Imam Busari had initially acted in the capacity of the Chief Imam for fourteen years due to old age and illness of Imam Muhammad Lawal Abolarin. He however became a substantive Chief Imam between 1971 and 1975. The humility and contribution of Imam Busari to Islamic education in the town made most of who is who in Islam in the town to support the candidature of his son Alhaji Usman Kolawole Babade to the Imamate. All objections to this were therefore put to rest with the appointment of Shaykh Usman Kolawole as the Chief Imam of the town on March 30 $1975 . .^{\text {th }}$

The sickness of Shaykh Usman Kolawole in 1998 which started at the eve of Ileya festival ('Id al-Adha) made the Imam sent the khutbah to the Mufassir of the town, Alhaji Shaykh Muhammad Raji Balogun to lead the 'Id prayer on his behalf. This step followed the Islamic principle of appointing the most knowledgeable in Islam to lead prayers, as the Mufassir was next in rank to the Imam in the absence of Naibul-Imam. The seriousness of the Imam's illness did not allow him to perform his official responsibility, and this made the Mufassir to stand in for him for almost twelve years. The length of the illness became a matter of concern to the Imam's house who suspected that should the Imam die without retrieving what they considered their right from the Mufassir, the baton of Imamship would totally be taken away from their house. They therefore levied some allegations on the Mufassir ranging from his nonremittance of the proceeds of the Imamship to the house of the Imam,

\footnotetext{
${ }^{34}$ Oral interview conducted with Shaykh Muhammad Raji Balogun, the Mufassir of IlaOrangun, on $12^{\text {th }}$ June 2009.
} 
his decision to prepare khutbah different from the one given to him by the substantive Imam, to presenting himself as the Chief Imam of the town rather than as the representative of the Imam. For these reasons, they protested to the Orangun of Ila,Oba Abdul-Wahab, demanding that the staff of office and the khutbah with Mufassir be returned back to the house of Imam. Efforts were made to settle this development amicably but to no avail. The NACOMYO branch of the town facilitated a peace meeting, calling concerned Ila Muslim sons and daughters at home and Diaspora and well-meaning Muslim scholars to find a lasting solution to the problem. The meeting was however not successful, as the family of the Chief Imam did not honour the invitation. ${ }^{35}$

To drive home their demand, and in order to technically elbow out the Mufassir from the pulpit, the family of Imam decided to bring the ailing Imam to the mosque on $9^{\text {th }}$ April 2010 to carry out his initial official duty, but was assisted by a member of his family, Abdur-Razaq Abdulkarim, who read the khutbah and later started leading the prayer. This development amounted to having two persons in the minbar, namely the ailing Chief Imam and Abdur-Razaq. The development made the rest Muslim alfas to demand that the town was in need of Naibul-Imam (Deputy Imam) to which the Imam's family objected. When the Muslim youth in the town could no longer bear this, they came out that they would not tolerate Alhaji Razaq to continue leading them in prayer and that the Mufassir should be allowed to continue leading the prayer. This demand was publicly made on $13^{\text {th }}$ August 2010 and it led to civil unrest that some Muslim youth were arrested and the Central mosque had to be closed down. At a peace meeting that followed this, it was resolved that pending the resolution of the matter, neither the Mufassir nor any member of

\footnotetext{
35 The peace meeting was initiated by NACOMYO under the auspices of the current writer and subsequent ones.
} 
the Imam's family should lead the prayer next Friday, but that the NaibulImam of Ikirun should lead the prayer. Consequent upon this, the Orangun of Ila took a bold step by inviting the President League of Imams and Alfas of the South-west, Edo and Delta States who is the Chief Imam of Osogbo land, Shaykh Mustafa Ajisafe; the Chairman of Osun State Muslim Community (OSMC) Shaykh Olayiwola, the Mufassir of Ora, Chief Imams of Ikirun, Oyan, Otan Ayegbaju and some other towns, Ya'qub Imam Aliagan of the University of Ilorin, and some Muslim obas in Osun State, namely the Aragbiji of Iragbiji, Akinrun of Ikirun, Owa of Otan Ayegbaju and Oloyan of Oyan. Some prominent Muslims in the town, representatives of Imams and Alfas, representatives of Muslim youth, representative of Imam's family and some Muslim chiefs were also invited to the peace meeting. The meeting finally resolved that the Imam's family should allow the Mufassir to continue leading the prayers and that Ila Alfas should forget having a Naibul-Imam for the time being. It was also resolved that henceforth; the Islamic titles would be rotated amongst the five major quarters of the town. ${ }^{36}$ With this conclusion, the case was brought to rest, as the Mufassir of the town resumed the religious duty of standing in for the Chief Imam. The situation continued until the death of the Chief Imam in 2010.

Soon after the death of the Chief Imam Alhaji Usman Kolawole, his house forwarded the name of Alhaji Razaq Abdul-Kareem to the Orangun of Ila, while the League of Imams and Alfas in the town forwarded the name of Alhaji Abdul-Hameed Salahudeen. This occasion led the Orangun to demand that each quarter should present their candidates for the vacant Imamship post. Reacting to this, Alhaji Abdul-Hameed Salahudeen of Iperin, Alhaji Abdul-Karim Asisoloriiro of Isedo, Mallam

\footnotetext{
${ }^{36}$ This author served as the secretary of the group who took record of the resolutions made at the meeting.
} 
Ishaq Uthman Titiloye of Oke-Jigbo, Alhaji Muhammad Raji of Eyindi, and Mallam Abdur-Rasheed Kewuyemi of Oke-Ede contested for the post. The family of Chief Imam was given a slot of presenting its candidate; thus Alhaji Ibrahim Kolawole was presented. They were all exposed to rigorous oral and written examination by a screening committee set up by the Orangun of Ila. Members of the committee included Alhaji Muhammad Rabiu, the Deputy Imam of Ikirunland; Engineer AbdulHamid Taofiq, the Chief Imam of Federal Polytechnic, Ede; and Alhaji Abdur-Rasaq Babatunde Abdul-Raheem, the Chief Imam of the Osun State College of Education, Ila-Orangun. After the examination, Alhaji Abdul_Hameed Salahudeen emerged the winner and was declared the Chief Imam of Ila-Orangun. The second position went to Alhaji Muhammad Raji, who was declared the Naibul-Imam; Alhaji Ibrahim Kolawole emerged third and was declared Otun Noibi, while Mallam Ishaq Uthman came fourth and was declared Otun Mufassir of the town. The new Chief Imam was consequently turbaned on the $23^{\text {rd }}$ December 2010 at the Igbonnibi Township Hall.

The outcome of this exercise was not taken by the house of the Imam who felt its 'property' had been unjustifiably taken from them. The family therefore decided to take legal step of demanding for its right and so sued the Orangun of Ila and the newly appointed Chief Imam. The case, up till the time of writing this paper, is in court. It was initially filed at the High Court in Ila. The Court in its ruling submitted it could not hear the case because it was purely a religious matter which it had no jurisdiction to hear. Presently the case is in an Appeal Court at Akure. All attempts to settle it out of court have proved abortive. Muslims in the town thus became divided on the basis of Imamship which the Prophet urged Muslims to accept only if appointed to do so. 


\section{Challenges}

Syncretism is one of the major challenges facing the Ila Muslim community. It is observed that right from the inception of Islam in Ila-Orangun, early Muslim scholars had compromised early converts' faith by allowing them to freely practice Islam with syncretism. The appearance of Imam Mohammad Ibrahim at the occasion of Isinro, a kind of traditional festival in the town and the visitation of Imam Rufai Ahmadu to meet the leaders of traditional faith at Kaa Etu'fe are clear indications of the Muslim leaders' liberalism and soft-mindedness which encouraged syncretism among the adherents. Attempts to preach against this practice in the contemporary period had been met with stiff opposition by those who confessed Islam and at the same time partake in traditional religious practices. Those who preach against syncretism are tagged fundamentalists, fanatics and all sort of bad names. It should be mentioned that Alhaji Jamiu Kewuyemi, a notable preacher in the town preached vehemently against this practice and at various times, he had been at logger head with traditionalists in the town.

Closely related to that is the incessant clashes of Muslim scholars and the traditionalists in the town. It should be noted that most of the traditional practices involved secrecy where people would be forced to remain indoor for a whole day or more. According to Jimoh (1997), "anybody who disregarded the instruction or was misinformed of the rituals and was eventually caught contravening the so called directive would be sacrificed to the idols. ${ }^{37} \mathrm{He}$ cited the case of one Orangun Adebiyi Ijimogodo (1560-1581CE) and his wife, Adegbinrin who were caught martialed and were consequently condemned to sacrificial death for their disregard for

${ }^{37}$ L.A. Jimoh, "The Impacts of Alhaj Jamiu Kewuyemi Ayeniromo on the People of Ila L.G.A of Osun State" Long Essay of the Department of Religions, University of Ilorin, Ilorin, 1997, 12-16. 
the egungun rituals. ${ }^{38}$ Although this practice of human sacrifice could be said to have gone into oblivion, Ila still witness instances of imposition of unofficial curfew, obstruction of commercial activities, marauding and looting merchandise and blocking traffic, all in the name of traditional religious rituals. These have led to series of clashes between the traditional worshippers and Muslims in the town. What is amazing there is the reaction of some who are not abreast of their fundamental human rights and freedom and so accuse Muslims of intervening and obstructing traditional worshippers from performing their rites. Alhaji Jamiu Kewuyemi had had several cases of clashes with the traditionalists that had led to court cases. The Mufassir of Ila had an instance where a team of masquerades forced themselves into his house which served as an Arabic school, wounded him and some of his students. This equally led to a court case. To be factual, Ila-Orangun has witnessed many clashes between Muslims and masquerades like Aniwo, Lakade and Gbodorogun. At a point the immediate past Orangun, Oba William Ayeni had to intervene by asking Gbodorogun to go back home in a police van escorted by anti-riot policemen. When eventually he was to go out, he was denied passing along the stree of Oke-Ede along Alfa Jamiu's house in order to avoid trouble.

Just like egungun festival, the Aworo-Ose festival which is accompanied by a taboo of not meeting him in the mid-night till dawn during his outing has constituted a great disturbance to Muslims who have to go out early in the morning to observe their early morning prayer. There were instances when Aworo clashed with some Muslims while going for morning prayers. A Muslim preacher popularly called Ojise Olohun had been beaten seriously and his vehicle damaged, all in the name of meeting Aworo, whereas the Preacher was performing his daily routine morning preaching. Narrating his experience on the influence of Aworo festival

\footnotetext{
${ }^{38}$ L.A. Jimoh, "The Impacts of Alhaj Jamiu”...,12-16.
} 
on the academic programme of the College of Education hosted in the town, Olorunnisola observed:

When the College was first established in the late 70 s and early 80 s, the College has its academic periods disturbed by closing in the afternoon of the first day of the festival and on some occasions lectures started late on the second day. ${ }^{39}$

Based on the above experience, he (Olorunnisola) recommended that imposition of unnecessary curfew in the town during traditional festivals especially during daytime should be abolished.

Furthermore, the introduction of Western system of education could be said to have hampered the progress of Islam in the town. No sooner that the education system was introduced than the few Muslims who attended it were converted to Christianity and the little knowledge of Islam in them was eroded. The opportunity to white collar job blindfolded many to realise this havoc, and so they stuck to its acquisition as if they were glued to it. Efforts at checkmating this led to the establishment of the Ansar-Ud-Deen school, which eventually produced products who later became elites and started working for the religion in the town. In the present Ila, it could be said that the establishment of the Osun State College of Education in the town was a mixture of blessing and foe to the Muslim community there. While it provided ample opportunity for Muslim children to get admission into the College, the College facilitated proliferation of Pentecostal churches in the town to the extent that virtually all streets in Ila are littered with them. This development creates free access to Christian worship by Muslim children and many of them be-

\footnotetext{
${ }^{39}$ I.A. Olorunnisola, "Nigeria Culture and Religion in Conflict: A Case Study of Clash of Culture and Religion in Ila-Orangun". A Paper presented at the $16^{\text {th }}$ National Conference of the National Association for the Study of Religions and Education (NASRED) held at the Lagos State College of Primary Education, Epe, Lagos, between $22^{\text {nd }}$ and $25^{\text {th }}$ October, 2003, 8.
} 
came apostatised for one reason or the other.

One needs to mention that the attitude of Muslim parents to the Islamic education of their children has not been encouraging. Considering the date of the introduction of Islam to the town, coupled with the exposure of the Muslims who had studied outside Nigeria, it is unbelievable that Ila cannot up till now boast of a standard Arabic school. The Centre for Islamic Education of Alhaji Abdur-Raheem Abdur-Razaq along Osogbo road as standard as it is, could not operate on full time basis but only operates in the afternoon. In towns like Ikirun, Ede, Iwo, Ilorin and Ibadan, there are madrasahs that operate in the morning. Efforts to establish such schools on full-time basis by Alhaji Muhammad Raji Balogun, the Mufassir of Ila, and Alhaji Abdur-Razaq Raji proved abortive.

Not this alone, it is difficult to believe that ever since the inception of Islam in the town, the Muslims could not boast of a cemetery to bury their dead bodies. In view of the growing rate at which Muslim nonindigenes are residing in the town, it becomes difficult for such residents to get their dead relatives buried without taking such bodies to their native towns. This, to us is a serious oversight on the part of the Muslim community of Ila since these days. The absence of Muslim cemetery in the town constitutes to the rate at which Muslims bury their corpses in the front or back of their houses. This practice makes graves open to passing urine or dumping other filthy things on. Some go to the extent of erecting building on such graves. In Islam, passing urine or any other filth on the grave is detested. To even sleep or sit on the grave is detested as it was reported by Abu Hurayrah that the Prophet said: "For one of you to sit on a hot coal that would burn his clothes and reach his skin that is better for him than sitting on a grave." ${ }^{40}$ It needs to be mentioned

${ }^{40}$ M. Al-Jibaly, Funerals: Regulations $\mathcal{E}$ Exhortations, n.p.: Al-Kitaab \& As-Sunna Publishing, n.d., 272. 
that the efforts of the current Chief Imam of the town in converting the Muslim community landed property situated at Isedo area to a cemetery is highly commendable. It is hoped that the place will be opened for the purpose soonest.

Finally, one also expects that by now that there should be a Muslim hospital in the town in view of the appreciable number of Muslims in the town. It will be a great honour for Muslim women to be treated by female doctors as instructed in the Qur'an that both male and female should lower their gazes and that women should not expose their nakedness to anybody except to their husbands (Q24:30-31). Adebayo identifies the danger inherent in a male doctor attending to a female Muslim to the extent of diagnosing and examining genito-urinary or gynaecological conditions of female patients. Apart from the fact that a faithful woman becomes distressed if examined by a male doctor, the fasting of such a male doctor carrying out vagina examination during Ramadan is also at stake if he is a Muslim. ${ }^{41}$ It is on this basis that one feels that it is a great challenge for Muslims in Ila to expedite action on having a Muslim hospital in the town for the protection of dignity of their wives, daughters and mothers.

\section{Conclusion}

So far, we have discussed the inception of Islam in the ancient town of Ila and some factors responsible for its spread in it. In the same vein, efforts had been made to highlight the impact of the religion on the socio-economic and political lives of the people. In the same vein, some cogs in the wheel of the progress of the town have been identified. On this note,

\footnotetext{
${ }^{41}$ R.I. Adebayo, "Integrating Religiosity into the Health Sector: The Relevance of Islamic Values to Medical Ethics;" in Y.O. Imam (ed.) Religion and Health Sciences, Maiduguri: Association for the Study of the Interplay between Religion and Science (ASIRS), 2009, 109-124.
} 
it is convenient for us to conclude that for Islam to continue forging ahead in the town, Muslims have to inculcate the spirit of unity amongst themselves in spite of their divergences. They should work as a team in line with the Quranic injunction that urged Muslims to hold together with the rope of Allah and that they should not disintegrate. Once this is upheld, one is optimistic that Islam will continue to prosper in the ancient town of Ila.

\section{Bibliography}

Abimbola, Olayiwola. "Oke Festival” in Ila-Orangun (the Principal City of Igbomina People). Osogbo: Swift Prints Nig. Ltd, 2000: 56-62.

Adebayo, R. Ibrahim. "The Role of Traditional Rulers in the Islamization of Osun State (Nigeria)", Journal for Islamic Studies, vol. 30 (2010): 60-77.

Adebayo, R.Ibrahim. "The Introduction, Spread and Impact of Islam in Ila-

Orangun," in Ila Orangun (The Principal City of Igbomina People). Osogbo: Swift Prints Nig. Ltd, 2000: 84-110.

Adebayo, R.Ibrahim. "Integrating Religiosity into the Health Sector: The Relevance of Islamic Values to Medical Ethics;" in Imam, Y. Oyewole (ed). Religion and Health Sciences. Maiduguri: Association for the Study of the Interplay between Religion and Science (ASIRS), 2009: 109-124.

Adeniji, Femi. "The Introduction, Spread and Impact of Christianity in IlaOrangun, in Ila-Orangun, the Principal City of Igbomina People. Osogbo: Swift Prints Nig. Ltd, 2000: 111-131.

Adetoyi, Adeleke. A Short History of Ila-Orangun. Ila-Orangun: Iwaniyi Press, 1974.

Ajiboye, Segun Olufunminiyi. A History of Ila-Orangun. Ijebu-Ife: Adeyemi Press Ltd, 1993.

Ajiboye, Segun Olufunminiyi. "Facts and Myths in the Traditions of Origin of Yoruba People: A Case Study of the Foundation of Ila-Orangun”; in Ila Orangun (The Principal City of Igbomina People). Osogbo: Swift Prints Nig. Ltd, 2000: 1-16.

Al-Jibaly, Muhammad. Funerals: Regulations $\mathcal{E}$ Exhortations. n.p, Al-Kitab \& As-Sunna Publishing, undated.

Awolalu J. Omosade and Dopamu, P. Adelumo. West African Traditional Religion. Ibadan: Onibonoje Press and Book Industries Nig. Ltd. 1979. 
IJIMS, Indonesian Journal of Islam and Muslim Societies, Volume 5, Number 1, June 2015: 1-28

Fauzani, S. Mukhtasar Ahkam al-Janaiz. Makkah: Idarat Thaqafat wa Nashr, 1987.

Ibiloye, E.Olaniyi. "Diplomacy and Emirate Formation: The Integration of the Igbomina into the Ilorin Emirate in the 19th Century", African Nebula, Volume 1, No. 1 (February 2010): 76-84.

Ibrahim, Oladipo. Kwara; The Stream of Western and Northern Nigeria. Ilorin: Haytee Press \& Publishing Co. Nig. Ltd. 2012.

Jimoh, Lasisi Ayanda. "The Impacts of Alhaj Jamiu Kewuyemi Ayeniromo on the People of Ila L.G.A of Osun State," Long Essay of the Department of Religions, University of Ilorin, Ilorin, 1997.

Jolayemi, Joshua Adeleke. "The Foundation and Growth of Ila-Orangun up to 1500"; The College Review, a Quarterly Journal of Osun State College of Education, Ila-Orangun, volume 6, No. 1. (1996): 45-60.

Olaniyan, Adebayo. "Deities in Ila-Orangun" in Ila-Orangun (the Principal City of Igbomina People). Osogbo: Swift Prints Nig. Ltd. 2000: 47-55.

Olorunnisola, I. Adebayo. "Nigeria Culture and Religion in Conflict: A Case Study of Clash of Culture and Religion in Ila-Orangun". A Paper presented at the $16^{\text {th }}$ National Conference of the National Association for the Study of Religions and Education (NASRED) held at the Lagos State College of Primary Education, Epe, Lagos, between $22^{\text {nd }}$ and $25^{\text {th }}$ October 2003.

Salam, Babatunde Akande. Ajase-Ipo (A Foremost 'Ogbo' Bearer) in Focus. A publication of Directorate of Information and Protocol Palace of Olupo of Ajase-Ipo, 2010. 